\title{
Tense and Aspect in the Academic Writing of Arab L2 Learners of English: A Corpus-Based Approach
}

\author{
Mousa A. Btoosh \\ Fahad Bin Sultan University
}

\begin{abstract}
Correspondence concerning this article should be addressed to Mousa A. Btoosh, Dept. of English Language and Translation, College of Sciences and Humanities, P.O. Box 15700, Fahad Bin Sultan University, Tabuk, Saudi Arabia. E-mail: mousa.btoosh@gmail.com
\end{abstract}

\begin{abstract}
This study aimed at explicating the use of tense and aspect in the academic writing of Arab L2 learners of English. The scope was restricted to two absolute tenses (simple present and simple past), perfective and imperfective aspects, and verb-form errors arising from the deletion or addition of the third person singular-s besides the omission of copula and auxiliary verbs. The study was conducted on the basis of a comparative, quantitative analysis of the target forms between a learner corpus and a similar-sized native one. In pursuing and achieving the stated objectives, it also concentrated on the types and sources of the tense, aspect and verb form errors in learners' performance. In addition to the significant disparity between the two corpora in terms of the frequency count and percentage of most of the target forms, the findings confirmed learners' tendency to use more verbs than native speakers. Results also showed that learners' use of the preterit (simple past), and perfective and imperfective aspects were largely constrained by their L1 grammar and semantic interpretation of verbs (independent of the target language norm). Moreover, the findings revealed some common inconsistent erroneous forms attributed to the omission or addition of the third person singular-s and the omission of copula and auxiliary verbs. Several main factors were identified as potentially responsible for learners' errors, that is, inconsistency inherent in L2 rules, learners' limited exposure to (authentic) L2, overgeneralization, redundancy reduction, and language transfer. The findings suggest the need to introduce appropriate pedagogical methods to best present the target language rules.
\end{abstract}

Keywords: tense-aspect morphology, language corpora, Arab EFL learners, second language acquisition, verb-form errors

\section{Introduction}

Despite the universality of the concept of time, languages possess different grammatical and lexical means to encode it. This is plainly evident from the different lexical and grammatical units and features that languages have and employ to enable senders and receivers to identify how an expressed event is located in time. Comrie $(1985$, p. 8) distinguishes between three major categories used to express time: lexical composite expressions, lexical items and grammatical categories.

Lexical composite expressions involve slotting time specifications into the position of a syntactic expression such as last month, a year ago, etc. This set is potentially significant in a language that has linguistic means for measuring time intervals. Lexical items, which consist of one-word structures, include adverbials such as now, today, yesterday, etc. Unlike lexical composites and lexical items, grammatical categories involve a set of grammaticalized expressions of location in time. The grammatical expressions of time are temporal notions that are conveyed by means of two different but interrelated linguistic categories, namely, tense and aspect.

Irrespective of the means used to express tense and aspect in human languages, these two categories constitute the core of language and language learning on a broad scale. Moreover, these categories are often used to assess learners' mastery or non-mastery of language skills as they account for a considerable proportion of learners' 
errors. Therefore, shedding light on learners' interlanguage and accounting for the sources contributing to their ill-formed output are important for learners, teachers, and curriculum and textbook developers.

This study is devoted to examining tense, aspect and verb form errors in the academic writing of Arab L2 learners of English within a corpus-based approach. In so doing, the learner corpus providing the database of this study has been thoroughly examined with the aim of casting light on and accounting for the major tense, aspect and verb-form errors produced by learners during the course of their mastery of L2. For comparison purposes, the quantitative results have been checked against a similar-sized corpus of native speakers.

\section{Tense and Aspect}

Tense expresses the time of an event in relation to a specific reference time, while aspect expresses the duration or completion of an event. Tense is, thus, deictic in that it expresses the temporal location of an event in respect to a specific reference time. Deictic languages, such as English, rely heavily on words and expressions whose meaning is dependent on the context in which it is used. Comrie (1985) defines tense as "the grammaticalized expression of location in time "locating" the time of a situation relative to the situation of the utterance" (p. 9). It may be marked morphologically (by different verb conjugations: 'visit' vs. 'visited'), syntactically by means of auxiliary verbs (shall visit), or even by both of them (have visited). Based on the timeline notion of events, there are three tenses: present, past and future.

Aspect, in contrast, is non-deictic in that it is related to the temporal shape of a situation. For Comrie (1976), aspect is concerned with the internal temporal constituency of events, states, or actions, their structure, and the relations between them within a situation. In a more comprehensive account of the term, Leech, Cruickshank, \& Ivanič_(2001) define aspect as "the way we view an action or state, in terms of the passing of time" (p. 54). Drawing on this account, aspect refers to the situation-internal time. Categorically speaking, aspect can be expressed morphosyntactically through verbal endings and periphrastic constructions and lexically by way of the inherent lexical semantics of verbs (Smith, 1991; Verkuyl, 1994).

Quirk, Greenbaum, Leech, \& Svartvik_(1985) describe aspect as "a grammatical category, which reflects the way in which the verb action is regarded or experienced with respect to time" (p. 188). Accordingly, grammatical aspect refers to how an event is viewed with respect to time. For Comrie (1976), there are two categories of grammatical aspects, viz., perfective and imperfective. The former refers to events or actions that are viewed from outside as a completed whole with no reference to the internal structure. Imperfective aspect, in contrast, refers to an "internal temporal situation" with a specific time reference (Comrie 1976, pp. 18-25). Thus, the imperfective aspect presents an event from an internal view point (as ongoing or enduring) while the perfective one presents a completed event from an external perspective.

Unlike grammatical aspect, which is conveyed morphosyntactically, lexical aspect, refers to the inherent temporal (or aspectual) properties of verbs (Van Valin and LaPolla, 1997). That is, events or situations are classified according to their internal temporal features. Depending on their interaction with aspectual and temporal modifiers. Vendler (1957) classifies verbal predicates into four semantic categories: state, activity, accomplishment and achievement.

State verbs (e.g., know, love, taste, cost, etc.) express a state rather than an action; they do not have internal dynamism. Thus, they have no definite beginning or end. Activity verbs (e.g., walk, drive, jump, etc.), on the other hand, do not have an inherent endpoint. They involve an action that consists of successive phases over time and last for an interval of time. Though they encode actions that consist of successive phases, accomplishment verbs (such as write a letter, build a house and paint a picture) have an inherent endpoint and are gradual. Like accomplishments, achievement verbs (e.g., reach, realize, identify, win, recognize, etc.) have an endpoint but occur instantaneously. In addition to the Vendler-based classification of verb types, verbs can be classified semantically into three dimensions, namely, dynamicity, durativity and telicity (Comrie, 1976; Anderson, 1993; Smith, 1991).

Though they are independent categories, drawing a clear-cut distinction between tense and aspect has remained a controversial task over centuries. Moreover, it is rather puzzling to speak about tense without referring to aspect or contrariwise. 


\section{Tense and Aspect in English and Standard Arabic}

English is an inflectional language. Thus, based on the two verbal inflections in the tense system of this variety '-s' and '-ed', grammarians such as Palmer (1974) and Christopherson \& Sandved (1969), concur that English has two tenses, namely, present and past. They claim that 'will' and 'shall' do not belong to the tense system as they are rarely used to refer to 'pure future'. Comrie (1976) also asserts that tense locates a situation with reference to just present and past points in time.

Future in English is formed periphrastically. Therefore, future reference, which is conveyed by various verb forms, including modals, is not considered an absolute tense (Lock 1996; Blair 1984, among others). However, several other grammarians assert that the primary meaning of modals is to express future time reference and thus modal meanings are secondary (Dürich, 2005; Lock, 1996). For Downing \& Locke (1992, p. 352), "tense primarily involves visualizing events as points in a sequence, preceding or following a central point which is usually the present moment." Therefore, the reference and event time points precede, follow, or coincide with the speaker's location. Based on the arguments of the proponents of the three-tense notion, the English tense system consists of present, past and future (Dürich, 2005; Downing \& Locke, 1996; Leech, 1971; Quirk \& Greenbaum, 1973). Leech (1971) and Quirk \& Greenbaum (1973) illustrate that verb forms used to express future time in English can be sorted in terms of importance as follows: will/shall + infinitive, be going to + infinitive, present progressive, will/shall + progressive infinitive and simple present.

In addition to tense, Comrie (1976) argues that time is conveyed by means of aspect, which relates to time internal temporal constituency of a situation. Drawing on this notion, there are two aspects, that is, perfective and imperfective. The combination of tenses and aspects gives new verb forms to the same tenses. So, the combination of the present tense with imperfective by using the auxiliary 'be' and the suffix '-ing' gives rise to the present progressive while its combination with the perfective form by using the auxiliary 'has'/have' yields the present perfect. Combinations of the past tense with the imperfective by using the auxiliary verbs 'be' and the '-ing' suffix and the perfective by using the auxiliary verbs 'had' and the '-en' suffix yields past progressive and past perfect, respectively.

In Arabic, tense and aspect have been the subject of intensive research over the past decades. Generally speaking, Arabic has been categorized as an aspectual variety (Bishai, 1965; El-Hassan, 1987; Holes, 1995; Tritton, 1943; Salamah, 2019, among others). Mitchel \& El Hassan (1994) clarify that the Arabic verb forms are not concerned with tense differences. Rather, they are primarily concerned with aspectual differences realized (perfective) or unrealized (imperfective). Some researchers (i.e., Haywood \& Nhmad, 1962) argue that Semitic languages, including Arabic, are 'deficient' in regard to tense. Undoubtedly, this argument is mainly based on the lack of morphological expressions of tense.

Yet, some studies suggest that categorizing Arabic as an aspectual variety is unjustified since it does have tense (Fassi Fehri, 2000). The following examples show that Arabic morphological verb forms of the perfective, imperfective and future imperfective present deictic reference. A look at these examples shows some close resemblance between Arabic and English in this regard.
(1) fatah-a
l-walad-u
1-baab-a
open-perf.3.sg.m.
the-boy-nom
the-door-acc

'The boy opened the door'

(2) yaftah-u

l-walad-u

1-baab-a

open-imperf.3.sg.m. the-boy-nom

the-door-acc

'The boy opens/is opening the door'

(3) sawfa yaftah-u

l-walad-u

1-baab-a

will-open.3.sg.m.

the-boy-nom

the-door-acc

'The boy will open the door' 
Comrie (1976) asserts "the difference between the Arabic perfective and imperfective cannot be purely one of aspect” (p. 78). Rather, he asserts that Arabic perfective is a case of tense/aspect opposition.”

Arabic is a derivational variety. There are two verb forms in Standard Arabic (SA, hereafter), that is, 'almadisi' (the perfective) and 'almud sari؟' (the imperfective). The imperfective form is both suffixal (number feature) and prefixal (person), whereas the perfective form is only suffixal and it mainly indicates the past tense (Benmamoun 2000, 9. 176). The verbal stem is based on the root, which consists of just three or more consonants. Verbal derivatives are structured according to a set of patterns. Thus, consonants rather than vowels convey the verb's meaning. However, classifying Arabic as derivational should not conceal that it has inflectional morphology that is expressed by means of affixes to indicate person, number, mood and gender. The following examples illustrate this.

(4) Consonantal root

k-t-b 'write'

d-r-s 'study'
Perfective

katab-a write-perf- 3.sg.m. 'he wrote'

daras-at study-perf-3.sg.f.

'she studied'
Imperfective

yaktub-u write-imperf-3.sg.m.

'he writes'

tadrus-u study-imperf-3.sg.f.

'she studies'

In general, Arabic varieties distinguish between three types of sentences, namely, nominal, verbal and equational sentences (Btoosh, 2010). A sentence that begins with a noun is called a nominal sentence, as shown in (5).

(5) ?al bint-u the girl-nom. tamsah-u

mop-imperf.3.sg.f. 1-bait-a

the house-acc.

'The girl mops/is mopping the house.'

A verbal sentence, in contrast, is the one that begins with a verb, as exemplified in (6).

(6) tamsah-u

l-bint-u

1-bait-a

mop-imperf.3.sg.f.

the girl-nom.

the house-acc.

'The girl mops/is mopping the house.'

A sentence that does not contain a verb is referred to as an equational sentence. In fact, the lack of the copula verb 'yakuun' (be) in equational sentences is attributed to a general language specific parameter that disfavors the phonological manifestation of the verb 'yakuun' (be) in the present tense.

(7) ?al bint-u

dzamiilat-un

the girl-nom

beautiful-nom.

'The girl is beautiful.'

Based on the examples, Arabic equational sentences have neither lexical verbs nor copulas. Yet, this generalization is valid only when it comes to the present tense. The following examples show that the copular verb does surface in the past and future.

(8) kaan-at was-3.f.

'The girl was beautiful.'

(9) l-bint-u

the girl-nom

l-bint-u

the girl-nom dzamiilat-an

beautiful-acc.

dzamiilat-an

beautiful-acc.

'The girl will be beautiful.'

\section{Jordanian Arabic}

Jordanian Arabic (JA, henceforth), the native tongue of the subjects of this study, is the medium of daily conversations, home communication and informal settings in Jordan. Historically speaking, JA belongs to the 
Levantine Arabic family of dialects spoken in what was known historically as 'Greater Syria'. Irrespective of the differences among them, Arabic colloquial dialects, including JA, are to a large extent mutually understandable (Al-Shawashreh, 2016). However, JA, like other colloquial Arabic varieties, differs from SA in numerous features.

Unlike SA, JA lacks overt structural case marking on all lexical DPs. However, this variety shows a case distinction with pronouns. In terms of word order, JA is basically an SVO variety though it allows for other patterns (VSO, SOV, OVS, and OSV) under certain conditions and "with distinct syntactic and interpretive properties of each" (Jarrah, 2017, p. 6). Verbal predicates in this variety exhibit a full agreement (in terms of gender, number and person) with the topic and pronominal subjects in SVO word order pattern. However, "in VSO sentences, verbs either show full or partial agreement with lexical subject DPs whether definite or indefinite, and they can also show default agreement only with indefinite subjects "(Al-Aqarbeh, 2011). The following examples illustrate this.

(10) SA

?akal-a

1-Pawla:d-u t-tuffa:ћat-a

ate-perf.3.sg.m. the boys-nom the apple-acc.

'The boys ate the apple.'

Pal-Pawla:d-u Pakal-u t-tuffa:hat-a

the boys.nom. ate- perf.3.pl.m. the apple-acc.

'The boys ate the apple.'
JA

?akal-u l-wlaad t-tuffa:hah

ate- perf.3.pl.m. the boys the apple.

'The boys ate the apple.'

l-wla:d Pakal-u t-tuffa:hah

the boys.nom. ate-perf.3.pl.m. the apple

The boys ate the apple.'

The verb in JA, as shown above, displays full agreement with the subject (in terms of number, gender and person) in both word order patterns (SVO and VSO). However, the verb in SA fails to achieve full agreement in VSO word order. As far as the features under investigation in this study are concerned, it is unlikely that any of the learners' errors can be attributed to the peculiarities of JA. Instead, all instances of L1 influence or transfer cited here are attributable to the proto-Arabic irrespective of the vernacular in question.

\section{Previous Research on Learners' Interlanguage}

A person's ability to use language, think and conceptualize develops at the same time (Kreidler, 2002). For native speakers, language knowledge is, to a large extent, unconscious and implicit. However, for L2 learners language knowledge is highly conscious, and, thus, it is affected by several other factors, including the existence of previous knowledge. Research on SLA over the past three decades includes several hypotheses that seek to account for the L2 acquisition of tense-aspect morphology, including the Aspect Hypothesis (Andersen \& Shirai, 1994, 1996), Default Past Tense Hypothesis (Salaberry, 1999, 2008) and Discourse Hypothesis (BardoviHarlig, 1994).

Aspect Hypothesis states that first- and second-language learners are initially influenced by the inherent semantic aspect of verbs and predicates in the acquisition of tense and aspect markers associated with or affixed to these verbs (Andersen \& Shirai, 1994, p. 133). This hypothesis predicts an association of: (i) past marking with telic verbs; (ii) the perfective with the past (in languages that have a perfective/imperfective distinction); (iii) the progressive with dynamic verbs (and specifically activities); and (iv) no overextension of the progressive to stative verbs (Bardovi-Harlig, 2012, p. 484). According to the Default Past Tense Hypothesis, learners (during the very early stages of acquisition) are substantially affected by L1 transfer in the form of a generalized use of the perfective marker across lexical aspectual classes (Salaberry, 2008, p. 246). Discourse Hypothesis, on the other hand, asserts that "learners use emerging verbal morphology to distinguish foreground from background in narratives" (Bardovi-Harlig, 1994, p.43).

A close look at the literature shows that L1 transfer has remained a controversial source of errors, ranging from the perspective that it is the major barrier to L2 acquisition (Fries, 1945; Lado, 1957; Tarone, 1988), to being of limited, little or even no significance or impact (Selinker, 1972; Richards, 1974; Dulay, Burt, \& Krashen, 1982; Amenós-Pons, Ahern, \& Guijarro-Fuentes, 2018; Pamittan, 2019). Irrespective of the pro and con arguments regarding L1 transfer, most studies clearly indicate that L1 impact remains persistent even at advanced levels of proficiency. 
Research on the interlanguage grammar of Arab L2 learners of English has explicitly indicated that learners, regardless of their use of local varieties, generally experience difficulties related to misuse of verb tenses, tense marker deletion, and copula and auxiliary verbs deletion (Scott \& Tucker, 1974; Mukattash, 1978; El-Badarin, 1982; Thompson-Panos \& Thomas-Ružić, 1983; Btoosh, 2011, Alesawe; Klopfenstein, 2017; among others). Errors related to copula and auxiliary verbs deletion are primarily attributed to learners' L1 since all Arabic varieties have neither copula nor auxiliary verbs in the present tense. Ill-formed structures resulting from the misuse of verb tenses and tense marker deletion are generally attributed to several factors, including L1 influence, overgeneralization, ignorance of rule restrictions, redundancy reduction and developmental stages of learning. Undoubtedly, such findings are consistent with the outcomes of several pioneering post-behaviorism studies conducted on learners of English from various language backgrounds (Corder, 1967; Norrish, 1983; Richards, 1974; Schachter, 1974; de Kleine \& Lawton, 2018). Based on the findings of these studies, L1 constitutes neither the sole nor the primary source of learners' errors. Rather, it has been well-proven that intralingual errors - ill-formed structures resulting from incorrect generalizations, ignorance of rule restrictions, or incomplete application of rules - largely outweigh the interlingual errors.

Notwithstanding the divergent opinions expressed over L2 development and L2 competence, analyses of language samples produced by learners, regardless of their L1, have pointed to the existence of numerous features reflecting the structures of their L1 and rules of L2. For instance, the acquisition of the functional categories (of tense and aspect), which has been examined within the Universal Grammar and generative approach frameworks, shows that learners begin the L1 value parameters at early stages of acquisition (Brown, 2007, p. 291). However, the findings show that incomplete representations and fossilization prevent advanced L2 learners from achieving near native-like competence (Parodi, 2001; Sorace, 1993).

With the advent of machine-readable language corpora, new areas and fields of research, including the use of tense and aspect in representative naturally occurring data (rather than limited or hypothetical examples) have begun to receive greater attention and become top targets for extensive research worldwide. However, a close look at research devoted to investigating tense, aspect and verb form errors in the performance of Arab EFL learners within the corpus-based framework shows that this field has received little attention vis-à-vis the studies carried out via the traditional approaches. As far as the researcher can tell, no comprehensive study has been conducted on these forms within this framework, even though some preliminary attempts to tackle tense and aspect in learners' performance have been made (Hamada, 2008; Mammeri, 2015).

The present study, therefore, seeks to fill this gap by exploring the use of tense, aspect and verb forms in the academic writing of Arab L2 learners of English. In order to gain better insights on similarities and differences between learners and native speakers in terms of the used tenses and aspects, a frequency count of the number of occurrences of the target forms (in both corpora) has been conducted. Overall, this study is guided by the following research questions.

1. Do learner and reference corpora differ in terms of the frequency count and percentage of the six target verb tenses and aspects?

2. What are the most common tense, aspect and verb form errors characterizing learners' performance?

3. What are the major factors attributed to learners' errors?

\section{Research Hypotheses}

Based on the literature review, along with the findings of previous relevant empirical studies on tense and aspect, three hypotheses have been formulated.

1. There will be a sizable gap between the two corpora in terms of the frequency count and percentage of the absolute tenses, and imperfective and perfective aspects.

2. Learners' use of the perfective and imperfective aspects, auxiliary verbs and copula will be largely constrained by their $\mathrm{L} 1$ and the semantic interpretation of verbs.

3. Inconsistency inherent in L2 rules, L1 and overgeneralization will be the major contributing factors to learners' errors. 


\section{Materials and Methods}

\section{Background}

In light of the objectives stated above, this study focuses on the use of simple present and simple past tenses, perfective and imperfective aspects, and verb-form errors arising from the deletion or addition of the third person singular $-\mathrm{s}$ besides the omission of copulas and auxiliary verbs. A deliberate attempt has been made throughout the paper to probe the reasons underlying the deviations in the learners' use of the target forms and features. To this end, special attention has been paid to:

- Delineate the use, overuse, underuse and misuse of tense and aspect forms in the performance of Arab L2 learners of English;

- Identify, label and categorize learners' tense, aspect and verb form errors;

- Provide plausible explanations for the sources and types of learners' errors.

\section{Data Collection}

The data for this study consists of two corpora, that is, the Interlanguage Corpus of Arab Students of English (ICASE, ${ }^{1}$ hereafter) and the reference (native speaker) corpus extracted from the Louvain Corpus of Native English Essays (LOCNESS, ${ }^{2}$ hereafter). Both corpora, as shown below, are similar in terms of the genre (argumentative, literary and expository essays), learners' age and level and data collection procedures (timed and untimed essays).

\section{Learner Corpus}

The ICASE, which was compiled by the researcher, consists of 100,229 tokens (words). This corpus is made up of 608 primarily argumentative timed and untimed essays written by second through fourth-year Arab university students of English at six public and private universities in Jordan. The untimed essays were written as homework assignments, while the timed ones were written under exam conditions where students had time constraints. Students who had lived in an English-speaking country prior to compiling this corpus were deliberately excluded from the study sample. Also, students who completed less than fifty credit hours were excluded from the study sample. It also is worth mentioning that almost all of the students who participated in this study started learning English at the age of 12 (fifth grade), with five classes weekly. This means that prior to their university or college education, students had studied English for at least eight years. Furthermore, English is one of the core courses throughout the school period, and it constitutes almost $30 \%$ of the total grade of the General Secondary Education Certificate (GSEC, hereafter). No student can be admitted to a university or community college unless $\mathrm{s} / \mathrm{he}$ has passed the GSEC. This criterion ensures that mastering a considerable level of English is a prerequisite to university or even community college education. Students majoring in English language and literature at public and private universities are expected to complete approximately 90 credit hours in linguistics, translation, language skills and literature in addition to the university and college requirements, which are often taught in Arabic.

\section{Reference Corpus}

For comparison purposes, the target features have been compared to an isomorphic-sized corpus of native English essays. The reference or native corpus comes from LOCNESS, a corpus of argumentative essays written by American and British university students. To put it on equal footing with the learner corpus in terms of the number of tokens, only 100,229 tokens (words) have been extracted and used in this study.

\section{Tools}

For grammatical and statistical analyses, both corpora were annotated and processed with the aid of the following tools:

\section{- Part-of-Speech Tagger: C7 Tagset (in CLAWS)}

\footnotetext{
1 ICASE: Interlanguage Corpus of Arab Students of English (a corpus compiled by the author).

2 LOCNESS: Louvain Corpus of Native English Essays.
} 
- $\quad$ Concordancer and Wordlist: WordSmith suite of Tools (version 7)

- Platform: Windows

The two corpora were tagged with C7 tagset of the CLAWS tagger (Garside \& Smith, 1997). For better understanding of the part of speech tags used in the sections below, please see Appendix A, which lists the 137 tags that constitute this tagset.

\section{Results and Discussion}

In corpus linguistics, quantitative and qualitative analyses are used in combination (Leech, Hundt, Mair, \& Smith, 2009). In line with this general trend and in conformity with the objectives of the current study, this section is divided into two sub-sections. The first section presents the quantitative findings while the second one reports on the qualitative analyses.

\section{Quantitative Analysis}

In order to examine the variation between the learner and reference corpora in terms of the forms and features set for investigation as illustrated above, the annotated versions of the two corpora were processed through the WordSmith software program (version 7). The numbers in Table 1, which presents the overall frequencies of the target forms and features in the learner and native corpora, reveal a significant variation between the two corpora.

Table 1

Frequency Count and Percentage of Verb Tenses and Aspects in Learner and Reference Corpora

\begin{tabular}{|c|c|c|c|c|c|c|c|}
\hline $\begin{array}{ll}\text { Tenpus } & \text { Tense/Aspect }\end{array}$ & $\begin{array}{l}\text { Simple } \\
\text { present }\end{array}$ & $\begin{array}{c}\text { Simple } \\
\text { past }\end{array}$ & $\begin{array}{c}\text { Present } \\
\text { progressive }\end{array}$ & $\begin{array}{c}\text { Past } \\
\text { progressive }\end{array}$ & $\begin{array}{l}\text { Present } \\
\text { perfect }\end{array}$ & $\begin{array}{c}\text { Past } \\
\text { perfect }\end{array}$ & Total \\
\hline Learner & $\begin{array}{c}4213 \\
(69.20 \%)\end{array}$ & $\begin{array}{c}1487 \\
(24.43 \%)\end{array}$ & $\begin{array}{c}124 \\
(2.04 \%)\end{array}$ & $\begin{array}{c}88 \\
(1.45 \%)\end{array}$ & $\begin{array}{c}128 \\
(2.10 \%)\end{array}$ & $\begin{array}{c}48 \\
(0.79 \%)\end{array}$ & $\begin{array}{c}6088 \\
(100 \%)\end{array}$ \\
\hline Reference & $\begin{array}{c}2887 \\
(63.35 \%)\end{array}$ & $\begin{array}{c}737 \\
(16.17 \%)\end{array}$ & $\begin{array}{c}139 \\
(3.05 \%)\end{array}$ & $\begin{array}{c}58 \\
(1.27 \%)\end{array}$ & $\begin{array}{c}654 \\
(14.35 \%)\end{array}$ & $\begin{array}{c}82 \\
(1.80 \%)\end{array}$ & $\begin{array}{c}4557 \\
(100 \%)\end{array}$ \\
\hline
\end{tabular}

A simple comparison between the numbers above reveals significant insights into the discrepancy between the two corpora with regard to the use of the target forms (of tense and aspect). In addition to the variations in terms of the overuse and underuse of the individual tense and aspect forms, Table 1 reveals that the learner corpus outpaces its reference counterpart in the total number of verbs (6088 vs. 4557), a finding that has been established in previous literature (Btoosh, 2004; Guo, 2006, among others). Therefore, the higher use of verbs in the learner corpus is not unexpected. In a more recent study, based on a comparison between the Brown Corpus (the Brown University Standard Corpus of Present-Day American English) and the Written English Corpus of Chinese Learners (WECCL), Yuanyuan (2017) points out that native speakers use more nouns and adjectives while Chinese EFL learners use more verbs.

Drawing on the numbers presented in Table 1, Arab EFL learners overuse simple present, simple past and past progressive and underuse present progressive, present perfect and past perfect. Using a two-sided Z-test of proportions, and based on the p-value, the statistical data indicates (as shown in Appendix B) that, except for the past progressive, the differences between the learner and reference corpora are all significant (at a significance level of $\alpha=0.05$ ).

The overuse of the simple present tense in the learner corpus is not surprising for three reasons. First, the native language of learners does not structurally distinguish between simple present and present progressive. As such, it is not uncommon for learners to use simple present where present progressive is expected. Second, it is a general tendency of learners to overuse of the simple present tense (Lauttamus, Nerbonne, \& Wiersma, 2007; Rogatcheva, 2014, among others). Moreover, it is a common practice of Arab EFL learners to start a discourse with an opening perfective narrative verb while (all) the subsequent verbs in the discourse are used in the simple present form, as shown in (11).

(11) Last year, I wanted to meet somebody, but I*do not (did not) know how to meet him. My friend *encourage (encouraged) me to go and meet him in the park. It *is (was) a great idea. 
A similar finding to the one presented in (11) has been reported by O'Brein (2003). Though the overuse of the simple past tense is a general tendency of learners (Wible \& Huang, 2003), it still sounds plausible, based on the learners' interlanguage, to attribute such variation to the learners' association of the telic predicates (achievement and accomplishment) with the simple past. This, of course, lends support to both the Aspect Hypothesis (Andersen \& Shirai, 1994, 1996) and Discourse Hypothesis (Bardovi-Harlig, 1994), since telic predicates show a tendency to occur in the foreground (material which provides the main points of the discourse), where the past form occurs recurrently. However, the underuse of the present perfect and past perfect forms in the learner corpus is chiefly attributed to the learners' failure to grasp the meanings and uses of these tenses.

Semantically speaking, the meanings of simple past and present perfect are distinctly realized by two forms in English while there is only one form underlying the two (meanings) in Arabic (Comrie 1976; Fassi-Fehri 2004; Bahloul 2008). Also, the perfect aspect in Arabic substantially corresponds to the simple past and past perfect tenses in English (Al Huneety, 2015, p. 125). Therefore, learners' use and nonuse of the perfective and imperfective aspects are constrained by their L1 grammar. Moreover, it is possible to attribute such variation to the avoidance strategy, whereby learners deliberately avoid using certain complicated forms (Schakhter, 1974; Btoosh, 2004). As a result, learners resort to various repairing strategies to compensate for their knowledge deficit, including the use of simple past as a substitute for the present or past perfect. Similar findings regarding learners' underuse of the perfect aspect are reported in Rogatcheva (2014).

\section{Common Tense and Aspectual Problems}

This section expounds on the major problems and deviations in the learners' use of tense, aspect and verb forms. By so doing, five sub-sections representing the most problematic areas for learners have been set for analysis. These sections detail errors resulting from the use and non-use of the punctive and durative verbs in the imperfective aspect, failure to distinguish between stative and dynamic verbs, improper use of the perfective aspect, omission or addition of the $3^{\text {rd }}$ person singular -s inflection, and omission of copula and auxiliary 'be' forms in compound constructions.

\section{Erroneous Non-use of the Progressive Form}

The disparity between the two corpora in terms of the number of the used simple present verbs is a bit suggestive, as mentioned above. From the examples provided in Figure 1 below, it seems clear that learners' substitution of the simple present for the present progressive is a feasible factor in accounting for such disparity.

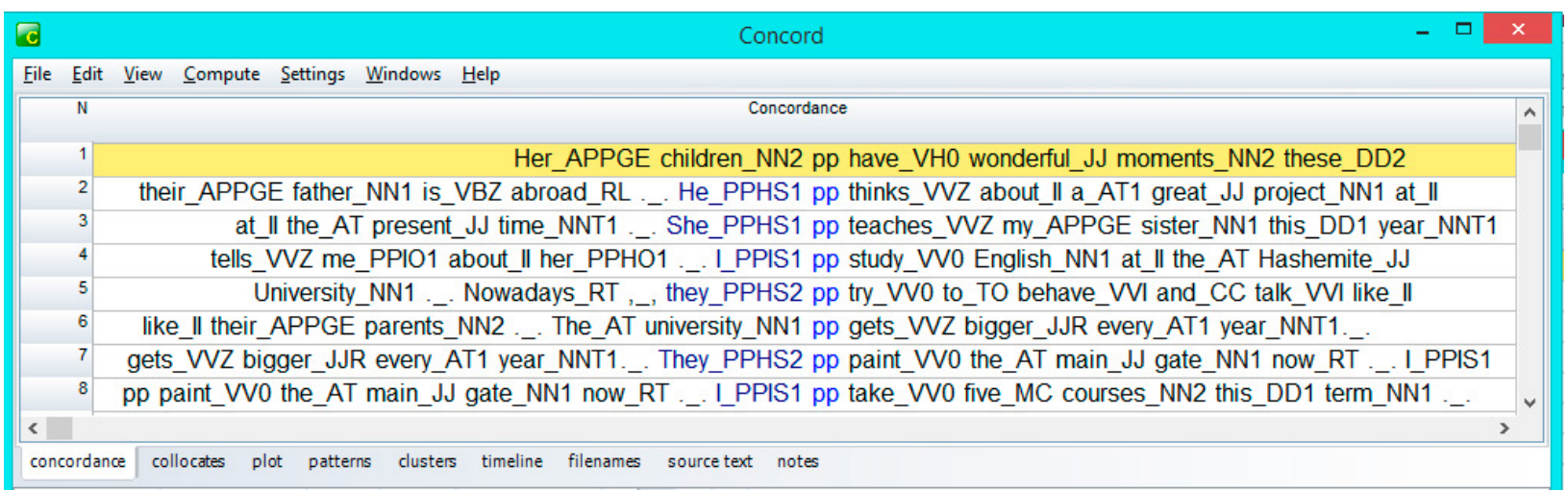

Figure 1. Substitution of simple present for present progressive.

The first two sentences shown in the concordance lines above present typical examples of the anomalous use of the simple present in environments where the present progressive would be used.

(12) Her children *have/are having wonderful moments.

(13) $\mathrm{He}$ *thinks/is thinking about a great project at the present time.

The erroneous non-use of the progressive aspect presented here stems from the learners' inability to distinguish between 'stative' and 'activity' meanings of certain verbs normally categorized as non-action verbs. For instance, neither have nor think in the examples above is used as a stative verb. Rather, they express actions as they mean 
'experiencing' and 'considering', respectively. While most of the time 'have' expresses possession, sometimes it is used to express an activity. This distinction is made explicitly clear in the following two examples: a person can possess a car (14) but cannot possess wonderful times (15).

(14) Tom has a spacious car.

(15) Her children are having wonderful moments.

Another common error in learners' performance involves using the simple present tense instead of the present progressive or durative aspect when referring to an activity taking place (around) now or temporarily, as shown in the lines below.

(16) I *study/am studying English (language) at the Hashemite University.

(17) She *teaches/is teaching my sister this year.

(18) Nowadays, they *try/ are trying to behave and talk like their parents.

The errors exemplified in (16), (17) and (18) above are basically attributed to L1 influence, where the present progressive tense is not expressed structurally. In learners' L1, the present simple form is also used to express the idea of a continuous action occurring in the present. Accordingly, unless an adverbial marker is added, the following two English sentences have the same meaning and translation in learners' L1:

(19) The student is living in London.

(20) The student lives in London.

\begin{abstract}
i țalib yaskun fi London
the student live-imperf.3.sg.m. in London

'The student lives/is living in London.'
\end{abstract}

It still remains reasonable to attribute the ill-formed structures presented in the concordance lines in Figure 1 to 'redundancy reduction'. Accordingly, learners seem to undervalue and thus eliminate the present progressive markers ('be' + V-ing) as the sentence meaning is preserved by means of the adverbial markers or signal words such as now, nowadays, listen, look, and at the moment of speaking. Therefore, the signal words are, according to learners, sufficient to express the intended time reference. In addition to learners' L1 influence and redundancy reduction, the errors presented in Figure 1 might reflect a gap in the learners' competence that is mainly attributed to inconsistency inherent in L2 rules, as shown in (12) and (13) above. Nevertheless, based on the responses of the instructors surveyed for this study, learners' limited exposure to L2 and instructors' high tolerance of learners' errors are directly responsible for learners' errors and their weaknesses in L2 skills, in general. According to these instructors, who were subjectively surveyed during the corpus compilation process, students do not get sufficient exposure to L2. They merely ascribe this to in-class code-switching (non-use of the target language) and instructors' simplification of L2 input (by relying on short summaries or nonauthentic textbooks). Besides, some surveyed instructors voiced their concerns regarding some professors' high tolerance of learners' errors. Previous research on learners' interlanguage provides evidence supporting these interpretations (Mohideen, 1996; Basiron, 2012; Köylü, 2018, among others).

\section{Erroneous Use of Progressive with Punctive and Stative Verbs}

Although less frequent compared to the progressive verbs mistakenly used in the simple present tense, learners sometimes use the past progressive in contexts where the simple past would normally be used. Figure 2 sheds some light on learners' erroneous use of punctual verbs in the imperfective aspect.

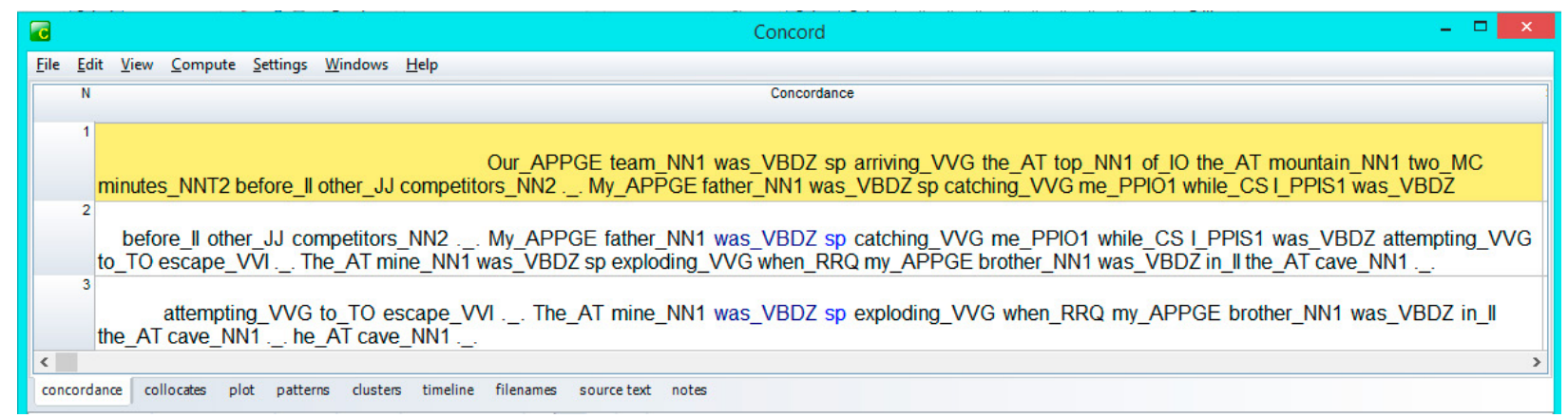

Figure 2. Using punctive verbs with progressive form. 
The instances above demonstrate learners' erroneous use of the past progressive with verbs denoting instantaneous (punctive) events. Punctive verbs, as illustrated below, are not conceived of as lasting in time and, thus, they cannot be used in the present or past progressive forms. The non-use of the progressive form with punctual verbs is attributed to "the difficulty of including the reference time within a temporal trace barely bigger than an instant” (Dini and Bertinetto, 2000, p. 27).

(21) Our team *was arriving/ arrived the top of the mountain two minutes before other competitors.

(22) My father "was catching/caught me while I was attempting to escape.

(23) The mine "was exploding/exploded when my brother was in the cave.

Aspectually speaking, punctive verbs (e.g. arrive, hit, win, etc.) describe instantaneous events (that denote a single or momentary action) while durative verbs (e.g. climb, wait, learn and study) denote a situation that takes place over a period of time. It seems obvious that the actions conveyed by the verbs in (21), (22) and (23) do not denote duration of time (as they are instantaneous events). This is the reason why the use of these verbs in the progressive form has rendered them ungrammatical.

Yet, it should be highlighted that punctual verbs that presuppose a preceding event are used in the progressive form, as shown in (24).

Rebecca was winning/won the race.

The use of the punctual verb with progressive in (24) presupposes that Rebecca participated in the race or was nearing the completion of the race (Engelberg, 1999:29-30). However, the frequency of using punctive verbs in the progressive form, irrespective of the interpretative logic, is relatively very low.

Figure 3 presents some more common types of intralingual errors, deviant forms resulting from the misuse of the target language rules.

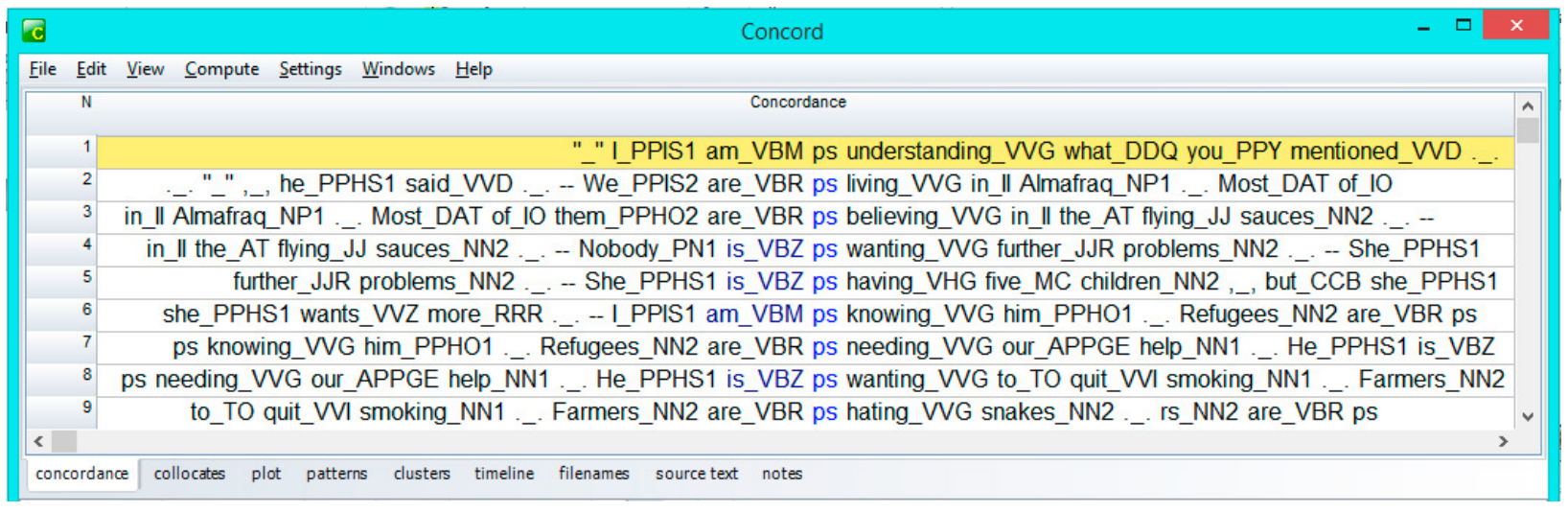

Figure 3. Substitution of present progressive for simple present.

All the erroneous forms shown in the concordance lines in Figure 3 are ascribed to learners' ignorance of L2 rule restrictions.

(25) I *am understanding/understand what you are saying.

(26) Most of them *are believing/ believe in the flying *sauces/saucers.

Both 'understand' and 'believe' are intellectual stative verbs and denote mental states. Therefore, the use of present progressive with theses verbs, as shown in (25 and 26), has rendered them ungrammatical since simple present rather than present progressive is normally used with non-action verbs. Accordingly, the learners' erroneous use of these verbs does not reflect their ignorance of the target language (present progressive) rules. Rather, it reflects their ignorance of the rule restrictions. Although the following sentence appears correct at first glance, it is contextually incorrect since the learner erroneously uses the present progressive to express a permanent action or an action that continues indefinitely. 
We *are living/live in Almafraq.

The seventh concordance line in Figure 3 presents another common error attributed to the effect of L2 rules on each other.

Refugees *are needing/need help.

Though the contextual meaning of this sentence denotes a temporary sense (now), the verb 'need' expresses a mental state, and thus it cannot be used in the progressive form.

\section{Erroneous Use and Non-use of the Perfective Aspect}

Learners' use of the simple past in contexts where the past perfect would be normally used does not usually pose a serious communicative problem since the time relation between the two activities remains quite obvious through the time words 'before' and 'after'. Nevertheless, what really matters here is the use of the past perfect in situations where the simple past would normally be used.

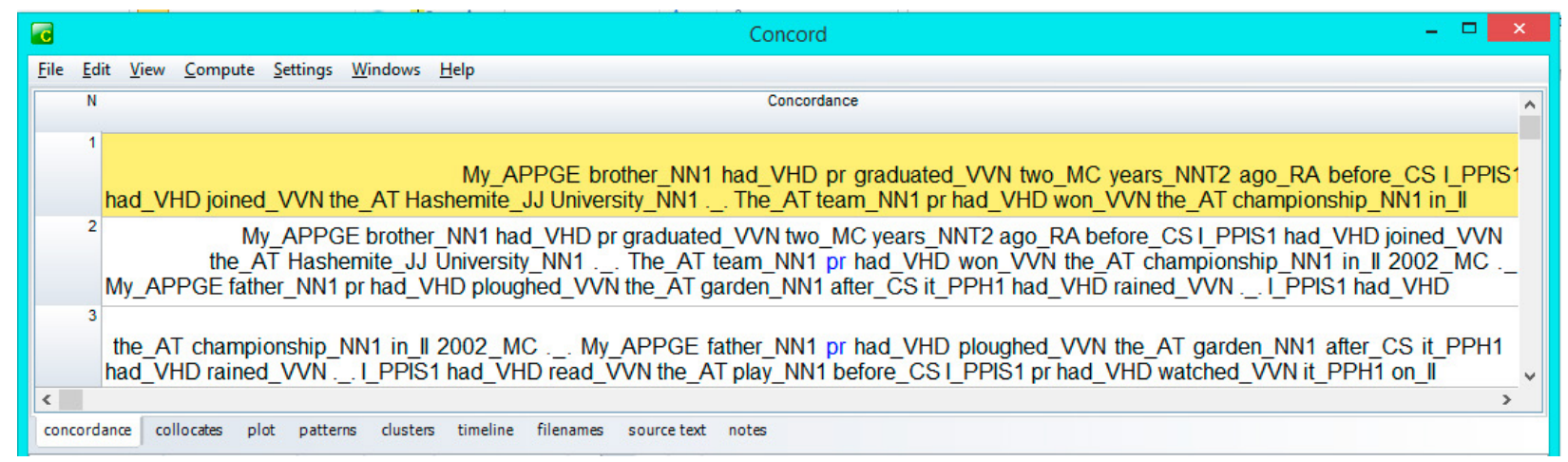

Figure 4. Erroneous use of the perfective aspect.

The use of the past perfect to express the 'earlier' and 'latter' actions, as shown in the concordance lines above, reflects a gap in learners' competence concerning the uses of the simple past and past perfect. In general, attributing learners' erroneous use or non-use of the past perfect to their L1 is reasonably justifiable as the Arabic perfect aspect largely corresponds to the simple past and past perfect tenses in English (Al Huneety, 2015, P. 125). Yet, hypercorrection remains feasible as some learners try to use more sophisticated structures just to sound more educated or native-like. Semantically speaking, the inappropriate use of the past perfect in environments where the simple past would normally be used sometimes leads to miscommunication as it makes the time order of events difficult to grasp, as shown in (29).

She had left when her boss had arrived.

The meaning here is rather obscure as the receiver cannot infer which action took place first in the past. However, the following erroneous examples illustrate that time order remains constant when time words 'before' and 'after' are used.

(30) My brother had graduated two years before I *had joined/joined the Hashemite University.

$$
\text { My father *had ploughed/ ploughed the garden after it had rained. }
$$

Learners' use of the past perfect with the 'latter' activity, as shown in (30), does not lead to a global error or misunderstanding since the time relation between the two activities is preserved by means of the time word 'before'. By the same token, inferring the intended meaning of sentence (31) does not present any difficulty for receivers since the time order is conveyed by 'after'.

Learners' choices of verb forms, as shown in the preceding sections, are negatively affected by the overlapping meanings of tenses and aspects. However, the concordance lines in Figure 5, show that learners' choices of the tense/aspect forms are also sometimes negatively affected by their L1 grammar. 


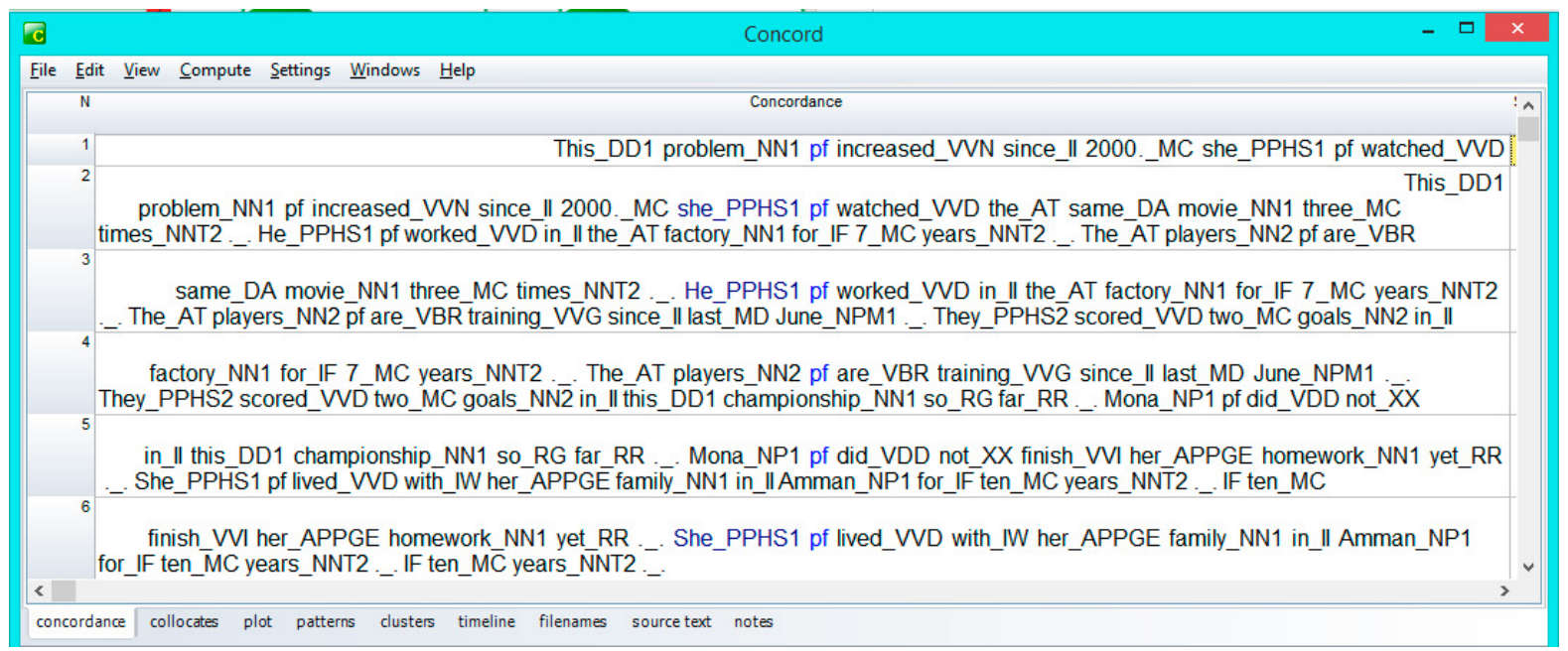

Figure 5. Erroneous non-use of the perfective aspect.

Using the simple past in environments where the present perfect is typically used, as shown in the concordance lines above, can be merely attributed to learners' L1 since the simple past and present perfect meanings are distinctly realized by two forms in English while there is only one form underlying the two (meanings) in Arabic (Comrie 1976; Fassi-Fehri 2004; Bahloul 2008). Therefore, replacing the present perfect verbs in all the following English sentences (32-35) by their corresponding simple past forms will not affect the meanings of the Arabic equivalent sentences as both tenses (present perfect and past perfect) are underlyingly identical in learners' L1.

(32) The problem *increased/has increased since 2000.

(33) She "watched/has watched the same movie three times.

(34) He *worked/has worked/ has been working at the factory for 7 years.

(35) The players *are training/have trained/have been training since last June.

However, due to the very nature and varied functions of the present perfect in English, the problematic construction of these sentences can also be accounted for independent of L1 transfer. Example (32), for instance, shows that the learner uses the simple past instead of the present perfect based on the past-time reference (2000), the date marking the beginning of the action. So, it seems rather obvious here that the learner mistakenly associates the past-time reference (2000) with the simple past tense. Example (33) also indicates that the learner erroneously uses the simple past to express a repeated action at an unspecified time (of completion) between the past and now (as the 'watching process' itself implicitly has taken place several times in the past). Sentence (35), on the other hand, presents another widespread error where learners use the present progressive instead of the present perfect based on the semantic interpretation of the verb since the denoted activity is still in progress (ongoing).

\section{Omission and Addition of the $3^{\text {rd }}$ Person Singular $-\mathrm{s}$}

Consistent with the findings of previous literature (Btoosh, 2011; Mukattash, 1978), the learner corpus contains plenty of instances where learners erroneously omit or add the third person singular inflection -s.

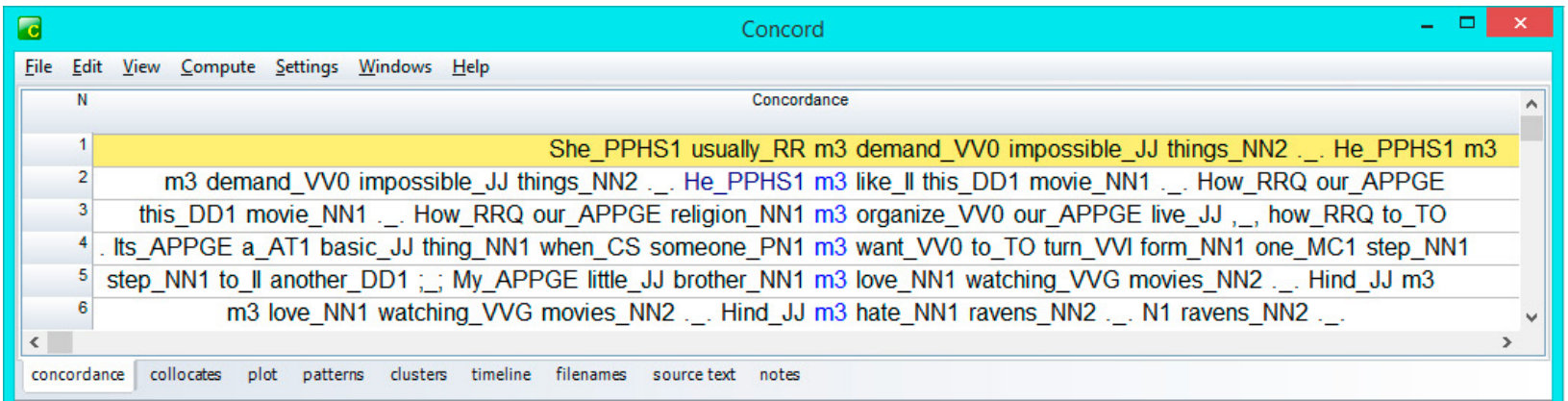

Figure 6. Omission of the $3^{\text {rd }}$ person singular -s. 


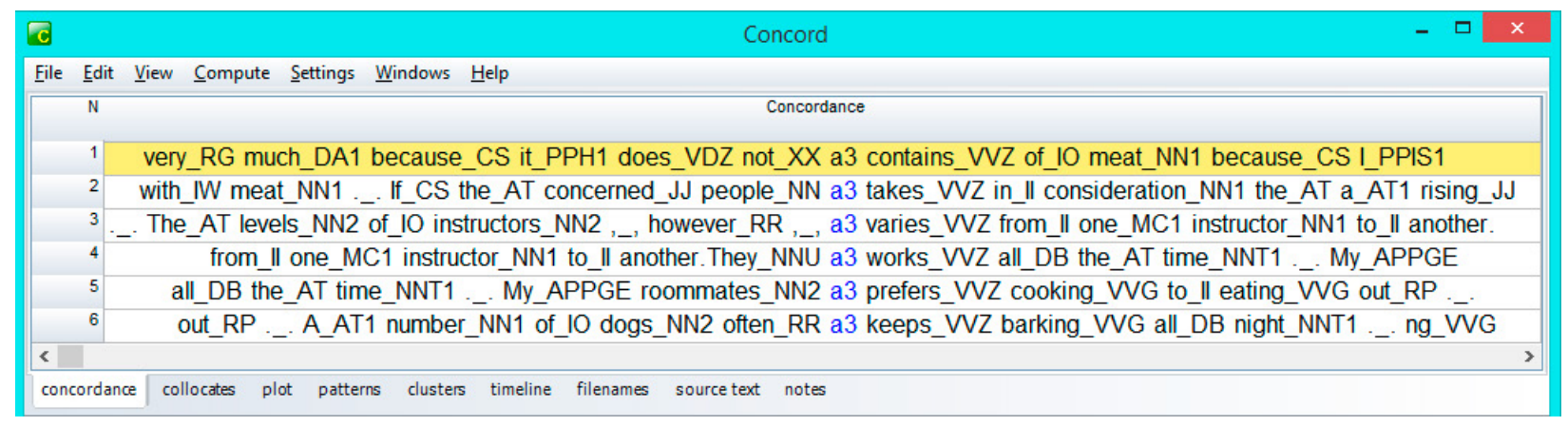

Figure 7. Addition of the $3^{\text {rd }}$ person singular -s.

As can be readily observed from the concordance lines in Figures 6 and 7, learners omit or add the $3^{\text {rd }}$ person singular -s in situations where it would, or would not normally, be used in L2, as illustrated in the following examples.

(36) She usually *demand/demands impossible things.

(37) $\mathrm{He}$ *like/likes this movie.

(38) How our religion *organize/organizes our lives...

(39) I like it very much because it *don't contains/doesn't contain meat...

(40) If the concerned people *takes/take into consideration the...

Due to the little semantic impact that the $3^{\text {rd }}$ person singular inflection (-s) has or possesses (as its presence or absence doesn't lead to a global error or misunderstanding), learners are likely to underestimate or undervalue its importance, which helps to explain this prevalent error in learners' performance vis-à-vis other deviant forms.

\section{Omission of Copula and Auxiliary Be}

Copula (be) deletion refers to the absence of the verb 'be' that joins the subject of the verb with the complement. The deletion of the copula in the performance of Arab L2 learners of English comes as no surprise since copula is not present in learners' L1 present tense verbless or equational sentences.

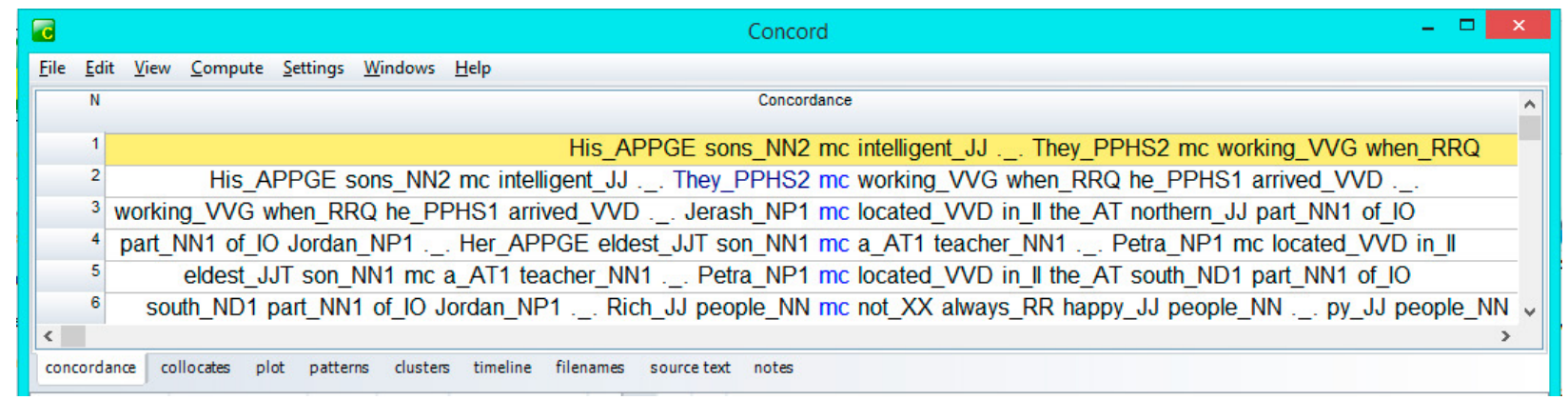

Figure 8. Omission of copula and auxiliary Be.

It should be made obvious that copula, which does not surface in the present tense in learners' L1, does surface in the past and future tenses, which helps explain the frequent omission of copula in learners' interlanguage in the present tense vis-à-vis its presence in the past and future tenses.

(41) His sons *intelligent/are intelligent.

(42) Her eldest son *a teacher/is a teacher.

(43) She *student/ is a student in the university.

Deletion of the auxiliary verb in composite verbs such as present and past progressive is another prevalent error in the learner corpus. The omission of the auxiliary verb occurs when a learner fails to remember the auxiliary or when s/he sacrifices the auxiliary at the altar of the main verb. 
(44) They *working/were working when he arrived.

(45) Jerash *located/is located in the northern part of Jordan.

Learners often overlook or underestimate the presence of the be auxiliary when attempting to form the present or past progressive, a fact that results in incomplete verb phrases, as shown in (44) and (45) above.

\section{Conclusion}

This study has sought to identify and account for the common tense, aspect and verb form errors produced by Arab EFL learners over their mastery of L2. For comparison purposes, the target features in the learner corpus have been checked against a similar-sized native speaker corpus. Results present five major types of learners' errors resulting from the erroneous use of punctive and stative verbs in the progressive form, non-use of the progressive aspect with verbs denoting activities, erroneous use and non-use of the perfective aspect, omission and addition of the $3^{\text {rd }}$ person singular $-\mathrm{s}$, and omission of copula and auxiliary 'be' forms. Based on the findings of this study, learners' errors are ascribed to two major and broad sources, that is, L1 transfer (interlingual errors) and misuse of L2 rules (intralingual errors). Based on an analysis of the data collected, two main results emerge: first intralingual errors include all erroneous instances attributed to overgeneralization, ignorance of rule restrictions, incomplete application of rules, misanalysis and hypercorrection; second, errors attributed to the misuse of L2 rules are more numerically signfiant than those attributed to L1 influence. Such findings are empirically consistent with the outcomes of previous research into the performance of other, non-Arab L2 learners of English (Corder, 1967; Richards, 1974; Brown, 1980; George, 1972; Kaweera, 2013).

Two pedagogical implications for language instructors and curriculum and textbook developers can be drawn from these findings. The first implication addresses the need to maximize learners' exposure to authentic L2 input inside and outside the classroom. The second implication suggests curriculum and textbook developers design learner-centered curriculum and pedagogy that meet learners' needs and make a meaningful difference to learners' educational experiences. This study leaves ample room for further exploration of numerous relevant themes, including the need to conduct longitudinal and contrastive studies to investigate the impact of computerbased learning, learner-centered curricula, and cooperative techniques of teaching, such as Student TeamsAchievement Division (STAD) and Team Game Tournament (TGT), on learners' L2 proficiency and writing skills.

\section{Acknowledgement}

This study was carried out during a sabbatical leave granted by Al-Hussein Bin Talal University, Jordan.

\section{References}

Al-Aqarbeh, R. (2011). Finiteness in Jordanian Arabic: A semantic and morphosyntactic approach (Unpublished doctoral dissertation). The University of Kansas, Kansas, USA.

Al Huneety, A. (2015). The phonology and morphology of Wadi Mousa Arabic (Unpublished doctoral dissertation). Salford University, UK.

Al-Shawashreh,E.(2016). Aspects ofgrammatical variation in Jordanian Arabic (Unpublished doctoral dissertation). University of Ottawa, Ontario, Canada.

Alesawe, A. A. (2015). A comparison of tense, aspect and voice systems of English, modern standard Arabic and Libyan dialects and the possible implications for the learning and using of English tense, aspect and voice by Libyan university students (Unpublished doctoral dissertation). The University of Leeds, Leeds, UK.

Amenós-Pons, J. Ahern, A. \& Guijarro-Fuentes, P. (2018). L1 French learning of L2 Spanish past tenses: L1 transfer versus aspect and interface issues. Studies in Second Language Learning and Teaching, 7(3), 489-515. doi: https://doi.org/10.14746/ssllt.2017.7.3.7.

Anderson, R. (1993). Four operating principles and input distribution as explanations for underdeveloped and mature morphological systems. In K. Hyltenstam \& A. Viberg (Eds.). Progression and Regression in Language: Sociocultural, neuropsychological, and linguistic perspectives (pp. 309-339). New York: Cambridge University 
Press.

Andersen, R., \& Shirai, Y. (1994). Discourse motivations for some cognitive acquisition principles. Studies in Second Language Acquisition, 16, 133-156

Andersen, R. W., \& Shirai, Y. (1996). Primacy of aspect in first and second language acquisition: The pidgin/ Creole connection. In W.C. Ritchie \& T.K. Bhatia (Eds.), Handbook of second language acquisition (pp. 527570). San Diego, CA: Academic Press.

Bardovi-Harlig, K. (2012). After process, then what? A longitudinal investigation of the progressive prototype in L2 English. In I. Saddour \& E. Labeau (Eds.), Tense, aspect and mood in First and Second Language Acquisition (pp. 131-151). New York, NY: Rodopi.

Basiron, H. (2012). A Statistical Model of Error Correction for Computer Assisted Language Learning Systems (Unpublished doctoral dissertation). University of Otago, Dunedin, New Zealand.

Benmamoun, E. (2000). The feature structure of functional categories: A comparative study of Arabic dialects. New York, NY: Oxford University Press.

Bishai, W. B. (1965). Form and function in Arabic syntax. Word XXI, 265-269.

Blair, K. (1984). Some perspectives on the tenses. FORUM, XXII(2), 32-35.

Brown, H.D. (1980). Principles of Language Learning and Teaching. New Jersey, HJ: Prentice-Hall Inc.

Brown, H. D. (2007). Principles of LanguageLlearning and Teaching (5th ed.). New York, NY: Pearson ESL Education. Btoosh, M. A. (2004). Interlanguage lexicology of Arab students of English: A computer learner corpus based approach (Unpublished doctoral dissertation). The University of Texas at Arlington, TX, USA.

Btoosh, M. A. (2010). Wh-Movement in standard Arabic: An optimality-theoretic account. Poznań Studies in Contemporary Linguistics, 46, 1-26.

Btoosh, M. A. (2011). Error types in the approximate system of Arab students of English: A multiple classificatory taxonomy. Indian Journal of Applied Linguistics, 37(1), 97-114.

Christopherson, P., \& Sandved, A. (1969). An advanced English grammar. London, UK: Macmillan.

Comrie, B. (1976). Aspect. Cambridge, UK: Cambridge University Press.

Comrie, B. (1985). Tense. Cambridge, UK: Cambridge University Press.

Corder S. P. (1967). The significance of learner's errors. International Review of Applied Linguistics, 5, 161-169.

de Kleine, C., \& Lawton, R. (2018). An analysis of grammatical patterns in generation 1.5, L1 and L2 students' writings: A replication study. Journal of Second Language Writing, 42, 12-24. https://doi.org/10.1016/j. jslw.2018.10.003

Dini, L., \& Bertinetto P.M. (1995). Punctual verbs and the linguistic ontology of events. Quaderni del Laboratorio di Linguistica, 7, 123-160

Downing, A., \& Locke, P. (1992). A university course in English Grammar. New Jersey, NJ: Prentice Hall.

Dulay, H., Burt, M., \& Krashen, S. D. (1982). Language two. New York, NY: Oxford University Press.

Dürich, K. (2005). The acquisition of the English tense and aspect system by German adult learners (Unpublished Master dissertation). Chemnitz University of Technology, Chemnitz, Germany.

El-Badarin, M. N. (1982). Transfer, structural complexity, and learning strategies in the acquisition of English syntax by Arabic speakers (Unpublished doctoral dissertation). University of Texas at Austin, USA.

El-Hassan, S. A. (1987). Aspectual distinctions in English and written Arabic. IRAL, 25(2), 131-138.

Fassi Fehri A. (2000). How aspectual is Arabic? Table ronde internationale: Syntaxe du temps et de l'aspect, Université de Paris, 7, 15-18.

Fries, C. C. (1945). Teaching and learning English as a foreign language. Ann Arbor, Michigan: University of Michigan Press.

Garside, R., \& Smith, N. (1997). A Hybrid grammatical tagger: CLAWS4. In R. Garside, G. Leech \& A. McEnery (Eds.), Corpus annotation: Linguistic information from computer text corpora (pp. 102-121), London, UK: Longman.

George, H.V. (1972). Common errors in language learning. Rowley, MA: Massachusetts.

Guo, X. (2006). Verbs in the written English of Chinese learners: A corpus-based comparison between non-native speakers and native speakers (Unpublished doctoral dissertation). University of Birmingham, UK.

Hamada, T. I. (2008). A corpus-based error analysis of high school students'written English: a reflection on noticing and recasting (Unpublished master thesis). British University in Dubai, UAE.

Haywood, J., \& Nahmad, H. (1962). A new Arabic grammar of the written language. London, UK: Percy Lund, Humphries \& Co. LTD.

Holes, C. (1995). Modern Arabic structures, functions and varieties. London, UK: Longman.

Jarrah, Marwan Ali Saleem. (2017). Title, Subject extraction in Jordanian Arabic (Unpublished doctoral dissertation). Newcastle University, UK. 
Kaweera, Ch. (2013). Writing error: A review of interlingual and intralingual interference in EFL context. English Language Teaching, 6(7), 9-18. doi: https://doi.org/10.5539/elt.v6n7p9.

Klopfenstein, Ph. A. (2017). Tense and aspect constructions among Arabic L1 learners of English (Unpublished master's thesis). Saint Cloud State University, USA.

Köylü, Z. (2018). The use of L1 in the tertiary L2 classroom: Code-switching factors, functions, and attitudes in Turkey. Electronic Journal of Foreign Language Teaching, 15(2), 271-289.

Kreidler, C. (2002). Introducing English semantics. London, UK: Routledge.

Lado, R. (1957) Linguistics across cultures: Applied Linguistics for language teachers. Ann Arbor, Michigan: University of Michigan Press.

Lauttamus, T., Nerbonne, J., \& Wiersma, W. (2007). Detecting syntactic contamination in emigrants: The English of Finnish Australians. SKY Journal of Linguistics, 20, 273-307.

Leech, Geoffrey. (1971). Meaning and the English verb. Harlow, UK: Pearson Education Limited.

Leech, G., Cruickshank, B., \& Ivanič, R. (2001). An A-Z of English grammar and usage. Harlow, UK: Pearson Education.

Leech, G., Hundt, M., Mair, C., \& Smith, N. (2009). Change in contemporary English: A grammatical study. Cambridge, UK: Cambridge University Press.

Lock, G. (1996). Functional English grammar: An introduction for second language teachers. New York, UK: Cambridge University Press.

Mammeri, S. (2015). A morphosyntactic study of efl students' written compositions: A corpus based analysis. Arab World English, 112-126.

Mitchell, T. F., \& El-Hassan, S. (1994). Modality, mood and aspect in spoken Arabic with special reference to Egypt and the Levant. London, UK: Kegan Paul International.

Mohideen, H. (1996). Error analysis - Contributory factors to students' errors, with special reference to errors on written English. The English Teacher, 25, 1-10.

Mukattash, L. (1978). A pilot project in common grammatical errors in Jordanian English. Interlanguage Studies Bulletin, 3(2), 250-291.

Norrish, J. (1983). Language learners and their errors. London, UK: The Macmillan Press.

O’Brien, J. (2003). Tense and aspect in the interlanguage of Gulf Arab learners of English (Unpublished doctoral dissertation). The University of Leicester, Leicester, UK.

Palmer, F.R. (1974). The English verb. London, UK: Longman.

Pamittan, F. A. (2019). The impact of mother tongue on the performance of ESL students' in listening and speaking skills embracing Mother Tongue Based- Multilingual Education (MTB-MLE) curriculum. The Asian ESP Journal, 15(1.2).

Parodi, T. (2001). Optionality in developing grammars: Pronouns and clitics in L2 acquisition. Retrieved from http:// citeseerx.ist.psu.edu/viewdoc/download?doi=10.1.1.501.7416\&rep=rep1 \&type=pdf

Quirk, R., \& Greenbaum, S. (1973). A university of grammar of English. London, UK: Longman.

Quirk, Randolph, Greenbaum, S., Leech, G., \& Svartvik. J. (1985). A comprehensive grammar of the English language. London, UK: Longman.

Richards, J. (1974). A non-contrastive approach to error analysis. In J. Richards (Ed.), Error analysis: Perspectives on Second Language Acquisition (pp. 172-188). Essex, UK: Longman.

Rogatcheva, S. (2014). Aspect in learner writing: A corpus-based comparison of advanced Bulgarian and German learners' written English (Unpublished doctoral dissertation). Giessen, Justus-Liebig-Universität Giessen, Germany.

Salaberry, R. (1999). The development of past tense verbal morphology in classroom L2 Spanish. Applied Linguistics, 20, 151-178.

Salaberry, R. (2008). Marking past tense in second language acquisition: A theoretical model. London, UK: Continuum.

Salamah, D. A. (2019). The Arabic aspectual marker Qad from the perspective of the two-component theory of aspect. Journal of Language and Education, 5(1), 49-62. doi: https://doi.org/10.17323/2411-7390-2019-5-149-62.

Schachter, J. (1974). An error in error analysis. Language Learning, 24, 205-214.

Scott, M. S., \& Tucker, G. R. (1974). Error Analysis and English language strategies of Arab students. Language Learning, 24(1), 69-79.

Selinker, L. (1972). Interlanguage. International Review of Applied Linguistics, 10(3), 209-231.

Smith, C. (1991). The parameter of aspect. Dordrecht, Netherlands: Kluwer Publishers.

Sorace, A. (1993). Incomplete vs. divergent representations of unaccusativity in non-native grammars of Italian. 
Second Language Research, 9(1), 22-47.

Tarone, E. (1988). Variation in interlanguage. London, UK: Edward Arnold.

Thompson-Panos, K., \& Thomas-Ružić, M. (1983). The least you should know about Arabic: Implications for the ESL writing instructor. TESOL Quarterly, 17(4), 609-623.

Tritton, A. S. (1943). Teach yourself Arabic. London, UK: Hodder and Houghton.

Van V., Robert D., Jr., \& LaPolla, R. J. (1997). Syntax: Structure, meaning and function. Cambridge, UK: Cambridge University Press.

Vendler, Z. (1957). Verbs and times. Philosophical Review, 66(2), 143-160.

Verkuyl, H. (1994). A Theory of aspectuality: The Interaction between temporal and atemporal structure. Cambridge, UK: CUP.

Wible, D., \& Huang, P.-Y. (2003). Using learner corpora to examine L2 acquisition of tense-aspect markings. In D. Archer, R. Rayson, A. Wilson \& T. McEnery (Eds.), Proceedings of the corpus linguistics 2003 conference (pp. 889-898). Lancaster, UK: Lancaster University.

Yuanyuan, H. (2017). A corpus-based contrastive study on Brown A \& B and WECCL. In L. Sun, L. Hale, Q. Fan \& J. Zhang (Eds.), Proceedings of the sixth northeast Asia international symposium on language, literature and translation (pp. 171-178). Georgia: The American Scholars Press, Inc. 


\section{Appendix A}

UCREL CLAWS7 Tagset (retrieved at http://ucrel.lancs.ac.uk/claws7tags.html)

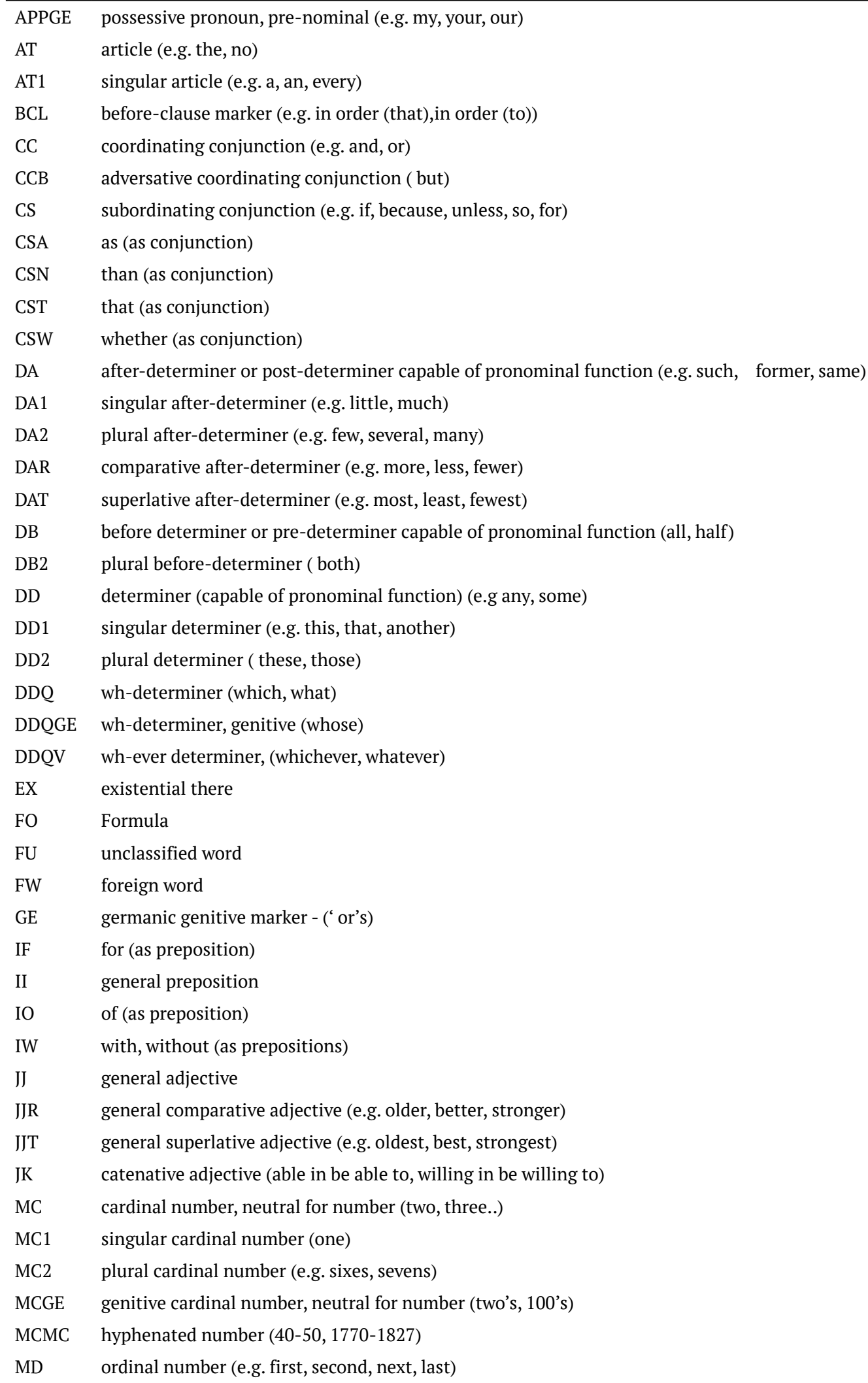




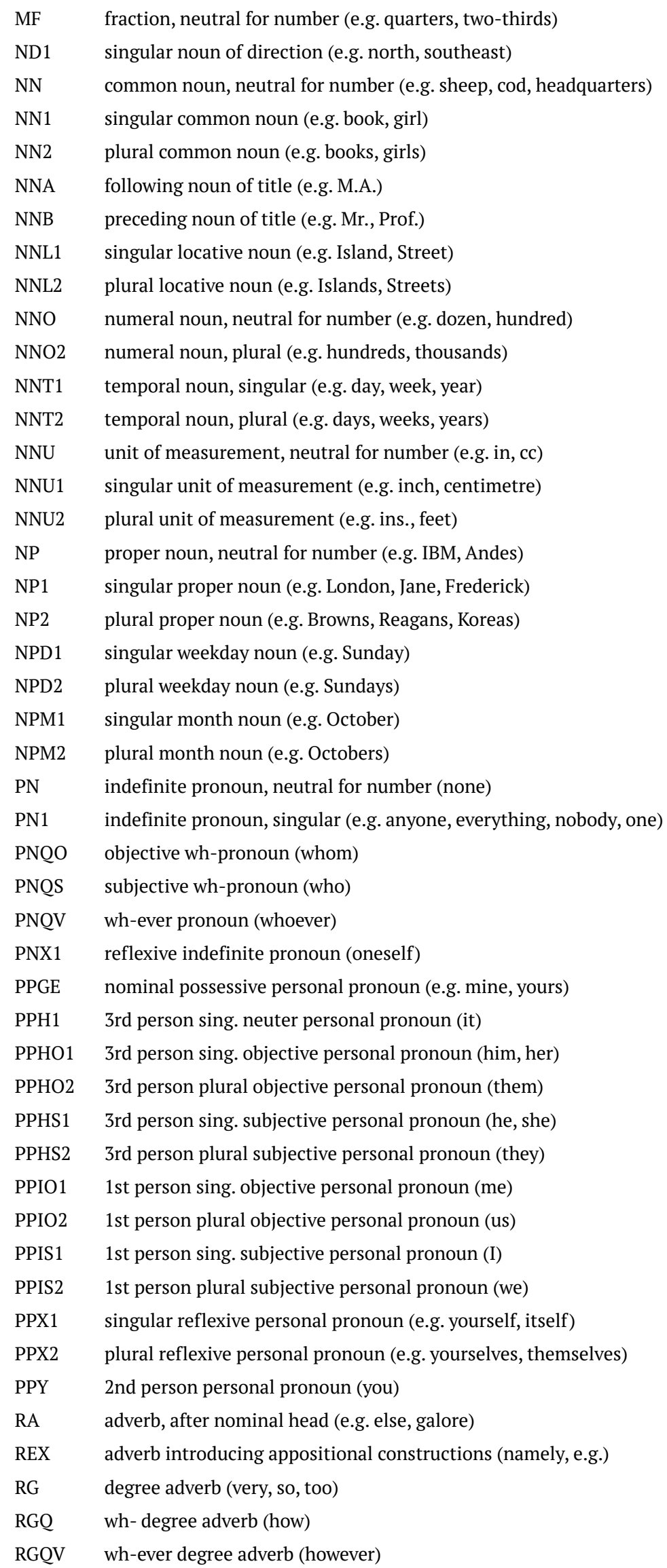




\section{MOUSA A. BTOOSH}

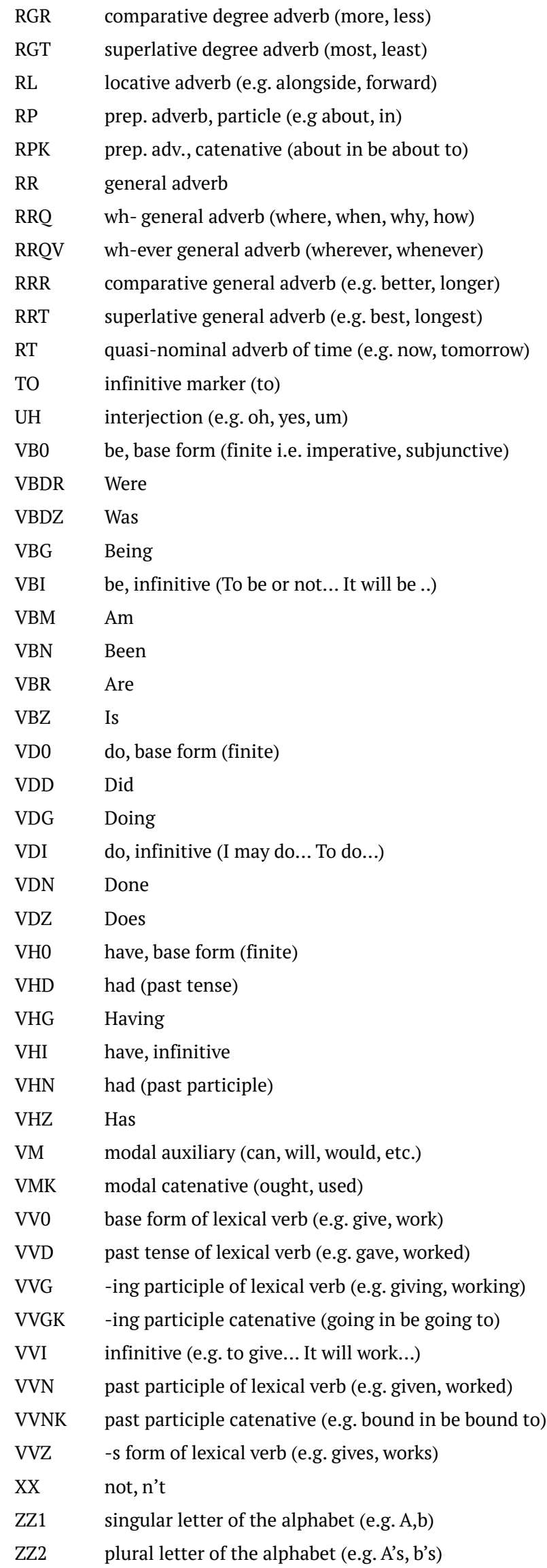




\section{Appendix B}

Frequency Count and Percentage of Verb Tenses and Aspects in Learner and Reference Corpora

\begin{tabular}{|c|c|c|c|c|c|c|c|}
\hline Corpus & $\begin{array}{c}(1)^{*} \\
\text { Simple } \\
\text { present }\end{array}$ & $\begin{array}{c}(2)^{*} \\
\text { Simple } \\
\text { past }\end{array}$ & $\begin{array}{c}(3) \\
\text { Present } \\
\text { progressive }\end{array}$ & $\begin{array}{c}(4) \\
\text { Past } \\
\text { progressive }\end{array}$ & $\begin{array}{c}(5) \\
\text { Present } \\
\text { perfect }\end{array}$ & $\begin{array}{c}\text { (6) } \\
\text { Past } \\
\text { erfect }\end{array}$ & Total \\
\hline Learner & $\begin{array}{c}4213 \\
(69.20 \%)\end{array}$ & $\begin{array}{c}1487 \\
(24.43 \%)\end{array}$ & $\begin{array}{c}124 \\
(2.04 \%)\end{array}$ & $\begin{array}{c}88 \\
(1.45 \%)\end{array}$ & $\begin{array}{c}128 \\
(2.10 \%)\end{array}$ & $\begin{array}{c}48 \\
(0.79 \%)\end{array}$ & $\begin{array}{c}6088 \\
(100 \%)\end{array}$ \\
\hline Reference & $\begin{array}{c}2887 \\
(63.35 \%)\end{array}$ & $\begin{array}{c}737 \\
(16.17 \%)\end{array}$ & $\begin{array}{c}139 \\
(3.05 \%)\end{array}$ & $\begin{array}{c}58 \\
(1.27 \%)\end{array}$ & $\begin{array}{c}654 \\
(14.35 \%)\end{array}$ & $\begin{array}{c}82 \\
(1.80 \%)\end{array}$ & $\begin{array}{c}4557 \\
(100 \%)\end{array}$ \\
\hline
\end{tabular}

Using a two-sided z-test of proportions, and based on the p-value, that statistical data show that, except for the past progressive, the differences between the learner corpus and reference corpus are all significant (at a significance level of $\alpha=0.05$ ).
$(1)^{*} \quad Z=6.342$, P-Value $<0.05$
(2)* $Z=10.382$, P-Value $<0.05$
$(3)^{*} \quad Z=3.323$, P-Value $<0.05$
(4)* $Z=0.790$, P-Value $<0.429$
(5)* $Z=23.980, P$-Value $<0.05$
$(6)^{*} \quad Z=4.695$, P-Value $<0.05$ 